\title{
References
}

1) Suzue, K. : Nihon Taishitsu-Gaku Zasshi, 25, 532 (1961). $\quad$ 2) Hasebe, H. : Jap. J. Legal Med., 16, 311 (1959). 3) Jankovic, B. D. : Acta haemat., 22, 278 (1959). 4) McKerns, K. W. and Denstedt, O. L. : Canad. J. Res., 28, 152 (1950). 5) Atwood, K. C. and Pepper, F. J. : Science, 134, 2100 (1961). 6) Filitti - Wurmser, S., Jacquot-Armond, Y., AubelLesure, G. and Wurmser, R. : Ann. Eugenics, 18, 183 (1954). 7) Boyd, W. C., Bhatia, H. M., Diamond, M. A. and Matsubara, S. : J. Immunol., 89, 463 (1962). 8) Grubb, R. : Acta path: microbiol. scand., 38, 339 (1956). 9) Hasebe, H. : Jap. J. Legal Med., 16, 325 (1962). 10) Yada, S., Naitow, M. and Hasebe, H. : Jap. J. Legal Med., 15, 475 (1961). 11) Nakajima, H., Hasekura, H. and Akabane, J. : J. Jap. Soc. Blood Transf., 9, 39 (1962).

\section{Immunohistochemical studies on some pancreatic enzymes.}

\author{
Kenjiro Yasuda \\ Department of Anatomy, School of Medicine, Keio Universitity Shinjuku, Tokyo, Japan
}

Since the histochemical method has its own limitation to be applied to demonstrate some enzymes, an immunohistochemical survey on certain enzymes, as an antigen, could be helpful to be used in this field. The immunofluorescence method developed by Coons is theoretically usuable, since most of the enzymes are known to act as the antigen to produce their specific antibodies (Cinader, 1957). The present work deals with the demonstration of some pancreatic digestive enzymes by means of immunofluorescent staining technique, thereby discussing the specificity of the antisera against these enzymes.

\section{Materials and methods}

The enzymes used were bovine and porcine pancreatic $\alpha$-amylase, bovine trypsinogen and chymotrypsinogen, of commercial origin. The antisera were prepared in rabbits against each enzymes, incorporated in to an adjuvant mixture of the Freund type (Freund, 1942). The emulsified mixture was injected subcutaneously into each footpad in a dose of $20 \sim 30 \mathrm{mg}$. of antigen for one rabbit, into each of four rabbits. Rabbits were given intravenous injection of $10 \mathrm{mg}$. of antigen four weeks after the first injection. The pooled sera were examined for the antibody titration by hemoagglutination test (Stavitsky, 1954). The antiservm against porcine $\alpha$-amylase gave a hemagglutination titer as high as $1: 1310720$. The rabbits sensitized with bovine trypsinogen developed a titer of $1: 40960$, those with bovine chymotrypsinogen produced a titer of $1: 40960$. For the titration of anti-trypsinogen- and anti-chymotrypsinogen-sera, equal weight (mg/mg.) of soybean trypsin inhibitor (Kunitz, 1947) was added to the antigens to prevent the antisera from being digested by the antigens, even 
though the soybean inhibitor exerted only a slight inhibiting effect on the proteolytic activity of chymotrypsinogen. Unless the inhibitor was added, the end point of the reaction was hardly read because of the obscure hemagglutination. The double diffusion-in-gel technique of Ouchterlony (1948) was used for the immunological analysis. The antigen-antibody systems of porcine $\alpha$-amylase as well as bovine chymotrypsinogen produced clear one precipitin line on the gel diffusion plates, while that of bovine trypsinogen shows four lines. One of the four lines in bovine trypsinogen-antitrypsinogen system fused with a line produced between bovine chymotrypsinogen-antitrypsinogen system, suggesting the presence of the immunological common factor between trypsinogen and chymotrypsinogen of bovine origin. A quantitative study of the precipitin reaction was carried out between porcine $\alpha$-amylase and homologous antiserum, according to Kabat and Mayer (1961). At a point of maximal precipitation, the ratio of $\alpha$-amylase to antibody was estimated to be ca $1: 10$. The $\alpha$-amylase activity was measured spectrophotometrically as described by Smith and Roe (1949). The antisera againt $\alpha$-amylase inhibited 77 per cent of the enzyme activity in a slight antigen excess, and 95 per cent in the optimum range From these immunochemical examinations, only the antiserum against porcine $\alpha$ amylase was proved to be suitable to be applied to the fluorescent-antibody technique. The fluorescein-labelled antibody was prepared and purified according to the techniques already described (Coons and Kaplan, 1950, McDevitt et al, 1963, Suzue and Hamashima, 1963). Frozen sections of $5 \sim 7 \mu$ thick were cut in a cryostat, followed by the brief fixation in $10 \%$ formalin and were subsequently examined by the immunofluorescence for exocrine cells of porcine pancreas containing $\alpha$-amylase, using appropriate controls.

\section{Observations}

Fresh frozen sections of porcine pancreas were stained for the demonstration of $\alpha$-amylase, after a fixation with $10 \%$ formalin. Other fixatives failed to fix the antigen in the tissue. Formalin-calcium also do not keep the antigen in the sections, even though calcium was thought to activate the biological reaction of amylase. In the formalin fixed frozen sections, the antigen was concentrated in the zymogen granules, and appeared diffusely in the homogenous area around the zymogen granules and at the basal cytoplasm of the acinal cells. The antigen was also encountered homogeneously around the nucleus but not abundantly in the apical cytoplasm. In contrast sections, stained with Mallory-Azan procedure, most of the zymogen granules were seen around or slightly above the nuclei, but not in the apical cytoplasm. The cells in the islets of Langerhans were entirely free of antigen. The apical cytoplasm of the cells in the inner layer of the interlobular duct showed homogenously a weak fluorescein. There was no visible antigen in the acinal lumen and also in the lumen of both intraand interlobular ducts. The antisera against bovine trypsinogen and chymotrypsinogen were applied on the sections, fixed with ethanol and embedded in paraffin. These antisera were found to be not suitable 
for immunohistochemistry because of their cross reactions with each heterologous antigen and also because of the difficulties in distinguishing the fluorescein of the dye from the autofluorescein of the granules.

\section{Discussion}

Not so much have been studied on the immunohistochemistry of the digestive enzymes, except the report of Marshall (1954) who made a survey on the distribution of chymotrypsinogen, procarboxypeptidase, desoxyribonuclease and ribonuclease in bovine pancreas. According to Hokin (1955), the zymogen granules of dog pancreas contain the highest amylase activity per mg. N, among the whole cellular components. But, fairly high activity was also recorded in several other fractions produced by centrifugation, i. e. nuclear and soluble fractions. In this study, the heterogeneous occurence of amylase was also recognized in the tissue sections; the amylase was not exclusively concentrated in the zymogen granules. As already described, the location of antigen could be summerized in or around the zymogen granules and in the homogeneous basal cytoplasm surrounding the nucleus. This distribution pattern of the antigen in tissue sections corresponds well with the wide range of distribution feature of amylase activity in several fractions obtained by centrifugation. The discrepancy between these results and the conventional concept that the digestive enzymes occur mainly in the zymogen granules is hardly explained. Hokin suggested that the amylase can be released from zymongen granules by the homogenization procedure, that the heterogeneity of the size of the zymogen granules caused the wide range of the distribution pattern of amylase in various fractions in the centrifugation and that the zymogen granules might be dissolved in some stages of the secretory procedure. From histological point of view, the heterogeneity of the distribution of amylase might depend on some condition of the secretory cycle of the pancreas, on the nutritional circumstance of the animals before being sacrificed in the slaughter house and finally on the procedure of preparing the sections; i. e. the choice of the fixatives, method in cutting the sections and the variety of the buffers used for rinsing the section before staining.

\section{Conclusion}

Immunofluorescence technique was applied to the pancreatic tissue for the demonstration of some digestive enzymes; amylase, chymotrypsinogen and trypsinogen. The antisera against porcine $\alpha$-amylase was proved to be immunologically specific enough to react with the antigen in the tissue. The porcine $\alpha$-amylase was encountered in the zymogen granules and also in the homogeneous area of the basal cytoplasm surrounding the zymogen granules and the nuclei. The cells in the islets of Langerhans were entirely free of antigen. The distribution pattern of $\alpha$-amylase in the acinal cells might be varible depending upon the various conditions of the secretory cycle and on the procedure of the preparation of the tissue sections. Because of the cross reactions in the antisera against trypsinogen and chymotrypsinogen, the exact location 

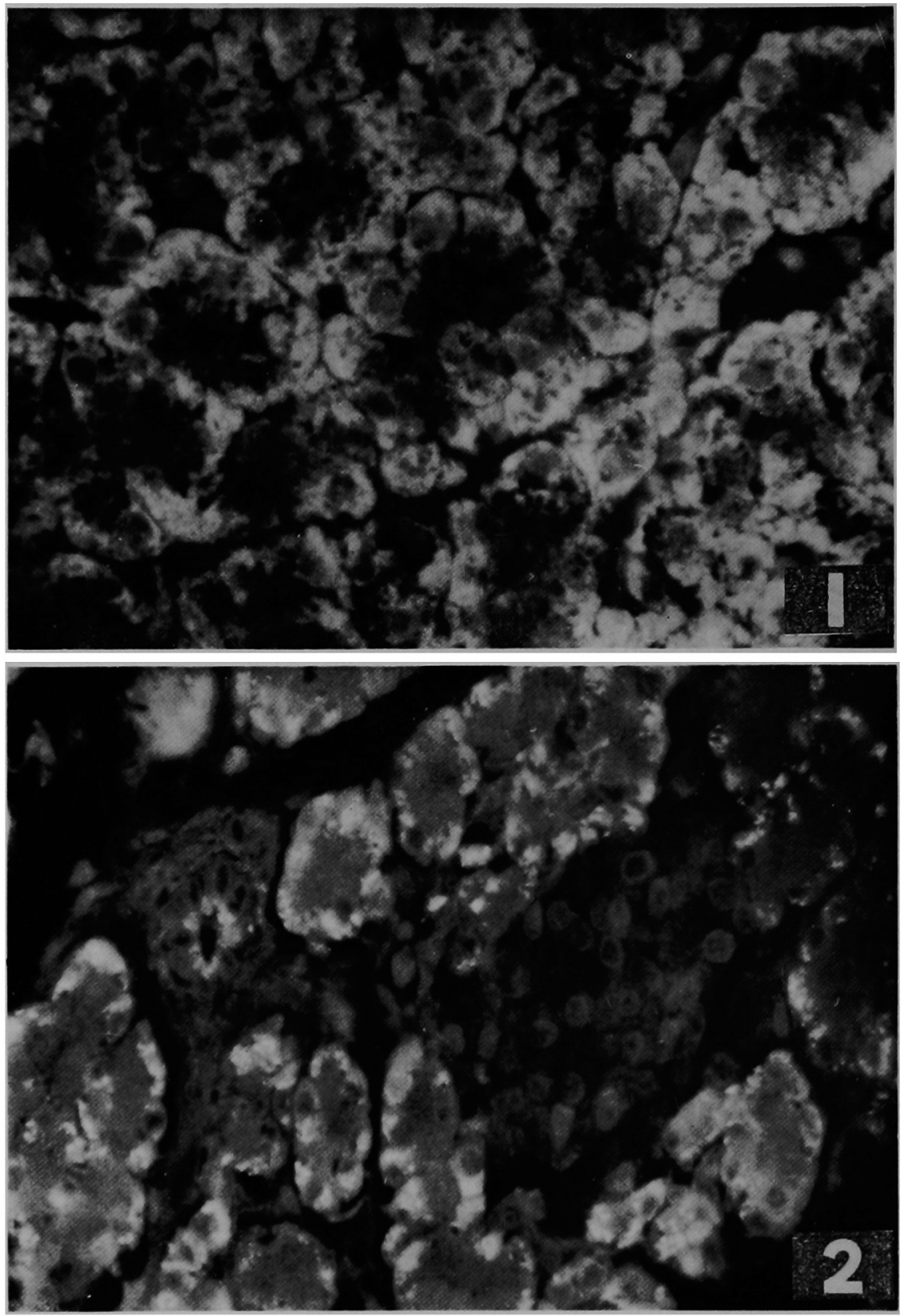

of these two enzymes was not clear even though they seemed to be concentrated in the zymogen granules. The attempt to investigate the homogeneity and heterogeneity of zymogen granules in the tissue section was also in vain.

\section{References}

1) Cinader, B. Antibodies against enzymes. Annual Review of Microbiology, vol. II, 371390, 1957, Annual Review Inc., Palo Alto, California. 2) Coons, A. H. and Kaplan, M. 
H. Localization of antigen in tissue cells. II. Improvement in a method for detection of antigen by means of fluorescent antibody. J. Exp. Med., 91 : 1-13, $1950 . \quad 3$ ) Freund, J. and McDermott, K. Sensitization to horse serum by means of adjuvants. Proc. Soc. Exp. Biol. \& Med., 49:548-553, $1942 . \quad 4)$ Hokin, L. E. Isolation of the zymogen granules of dog pancreas and a study of their properties. Biochim. Biophys. Acta., 18: 379-388, 1955. 5) Kabat, E. A. and Mayer, M. M. Experimental Immunochemistry, 1961, 2nd. Edition, Thomas Co., Springfield, Illinois. 6) Kunitz, M. Crystalline soybean trypsin inhibitor. II. General properties. J. Gen. Physiol., $30: 291-310,1947 . \quad 7)$ Marshall, J. M. Jr. Distributions of chymotrypsinogen, procarboxypeptidase, desoxyribonuclease, and ribonuclease in bovine pancreas. Exp. Cell Res, $6: 240-242,1954 . \quad 8)$ McDevitt, H. O., Peters, J. H., Pollard, L. W., Harter, J. G. and Coons, A. H. Purification and analysis of fluoresein-labelled antisera by column chromatography. J. Immunol., $90: 634-642,1963.9$ 9) Ouchterlony, Ö. Antigen-antibody reactions in gels. Arkiv. Kem. Mineral. Geol., 26B, 1-9, 1948.110$)$ Smith, B. W. and Roe, J. H. A photometric method for the determination of $\alpha$-amylase in blood and urine, with use of the starch-iodine color. J. Biol. Chem., 179; 53-59, 1949. 11) Stavitsky, A. B. Micromethods for the study of proteins and antibodies. I. Procedure and general applications of hemagglutination and hemagglutination-inhibition reactions with tannic acid and protein-treated red blood cells. J. Immunol., $72: 360-375,1954$. 12) Suzue, K. and Hamashima, Y. Fluorescent antibody technique, Igaku Shoin Ltd., Tokyo, 1963. (in Japanese) 13) Yasuda, K., Toyoshima, Sh. and Akiyama, T. Fluorescent antibody technique. 1. Modern Media, 8 (11) : 16-22, 1962-a, (in Japanese). 14) Yasuda, K., Toyoshima, Sh. and Akiyama, T. Fluorescent antibody technique. 2. Modern Media, 8 (12) : 22-30, 1962-b, (in Japanese). 15) Yasuda, K., Toyoshima, Sh. and Akiyam, T. Fluorescent antibody technique. 3. Modern Media, 9 (9) : 39-54, 1963. (in Japanese).

\section{Explanation of figures}

Fig. 1 The site of bright fluorescence indicates the localization of $\alpha$-amylase in the exocrine portion of the porcine pancreas. Amylase is mostly encountered in the cytoplasm around the nuclei which locate in the basal region of the acinal cells. The fluorescent material in the cytoplasm consists of zymogen granules and of some amount of homogeneous structure which occupies the interspace between granules. $\times 400$.

Fig. 2 The bovine trypsinogen is encountered mostly in the zymogen granules and in the granules in the apical cytoplasm of the cells of the inner layer of the interlobular duct. The cells in the islet of Langerhans are free of antigen. The dim fluorescein of the amorphous cytoplasm in the background of the granular structure is attributable to the autofluorescence produced by the paraffin-embedding procedure. $\times 400$. 